\title{
LA ENORME LIBERTAD DE LOS CUENTOS BREVÍSIMOS. ENTREVISTA A ANA MARÍA SHUA
}

\author{
SANDRA BIANCHI \\ Universidad de Morón (Buenos Aires)
}

Si hay una voz autorizada para hablar de los textos breves, se llamen con cualquiera de sus etiquetas de género, o mejor aún, cuentos brevísimos como ella prefiere llamarlos, es Ana María Shua, una escritora consagrada en la narrativa en general y en la breve en particular. Con ella conversamos sobre las prácticas de lectura y escritura y su preocupación por el cuidado de una forma que tiene para sí un lugar privilegiado en su producción literaria.

Sandra Bianchi: Tu obra Cazadores de letras (2009) es una suerte de obra completa hasta el momento de su edición, que luego prosiguió con Fenómenos de circo (2011). Con esa salvedad, ¿qué significa ver una obra micro así reunida, en una dimensión tan macro?

Ana María Shua: A mí me impresionó muchísimo ver el tamaño del libro Cazadores de letras, donde yo misma no tomo conciencia de lo que hice. Una cosa interesante es que al principio me oponía a la idea de Juan Casamayor, el editor de Páginas de espuma. Él estaba convencido de que quería hacer ese libro y yo le decía: "No, de ninguna manera, za quién le puede interesar un libro de microficción tan gordo? Pero por supuesto, él tenía razón, y sí, hay muchísima gente a la que le interesa. Yo estaba un poco acobardada por las dificultades de difusión que tiene el género, así que fue una agradabilísima sorpresa ver que el libro sí interesaba a los lectores. 
SB: Entre La sueñera (1984), tu primer libro de microficciones y el último, ¿qué cambios percibís en tu escritura de textos breves? ¿Están relacionados de algún modo con los cambios que experimenta el género?

AMS: Yo noto los cambios que se produjeron en mi escritura, no sé si eso tiene que ver con los cambios del género, creo que en mi caso no. El autor cuando escribe su primer libro lo escribe con mucha espontaneidad, pone todo lo que tiene, pone todo lo que sabe y hace todo lo que puede. Cuando va avanzando y escribiendo otros libros, uno de los elementos que pesan son los libros que ya tiene escritos, entonces la originalidad se hace cada vez más difícil. Un verdadero escritor no quiere repetirse, sueña con la maravillosa y casi imposible chance de no repetirse, de ser cada vez original y distinto en cada uno de sus libros. Yo dejo pasar muchos años entre un libro de minificción y otro, precisamente para evitar el autoplagio. Cuando escribí Fenómenos de circo, tenía cuatro libros de microficción que quería dejar atrás para hacer algo diferente y tengo la sensación que con el último lo conseguí. Primero porque el libro tiene un tema general -es la primera vez que encontré un tema general para todo un libro-; lo intenté otras veces pero no lo conseguí. La sueñera finalmente no es todo un libro de sueños, Botánica del caos (2000) no es un libro de plantas, como lo pensé en algún momento, que era escribir una especie de jardín botánico en clave de microficción, pero no lo logré y quedó solamente en un sector del libro. Lo mismo me pasó con Casa de geishas (1992), esa especie de burdel de la imaginación, que al principio iba a ser todo un libro y finalmente se convirtió en un sector. Y con el circo sí encontré un tema para todo el libro. Y también hice otra cosa nueva, diferente de los demás libros: me apoyé en datos históricos, en un trabajo de investigación donde los mismos datos me fueron dando la pauta y el desencadenante para que surjan las microficciones.

SB: ¿El trabajo de investigación colaboró para que lograras ese propósito de escribir un libro vertebrado por un tema general?

AMS: Yo sentí que lo primero que salió de la galera fue un mago. Es decir, primero se me ocurrió un mago, el mago tenía una galera, entonces al tirar de la galera aparecieron pañuelos, carpas, enanos, equilibristas...

$\mathrm{SB}$ : ¿Fue el mago entonces?

AMS: ¡Sí, fue el mago!

SB: En todos estos años creaste una obra narrativa tan vasta y diversa. Trabajás todos los géneros y todos los registros, porque también tenés libros de literatura infantil. ¿Cómo ubicás la microficción en una producción tan amplia?

AMS: Mi producción no es tan grande como parece, mis libros para adultos no son muchos. Tengo cinco novelas, tres libros de cuentos, tampoco es tan vasta, 
tengo sesenta y dos años y empecé muy muy jovencita. Dentro de esa producción para mí el microrrelato tiene un lugar muy privilegiado. Yo siento que ahí pude decir algo nuevo, encontré una nueva forma de narrar en la microficción. Es el género que más placer me da cuando lo estoy escribiendo, absolutamente. Una vez que uno encuentra la piedra de donde quizás salgan las joyas, uno empieza a trabajarla, a pulirla y si no sirve la tira, pero si sirve va a brillar ese mismo día. Eso es algo maravilloso. En cambio, con otros géneros "más largos" no sucede lo mismo. En el caso de un cuento, son semanas o meses, y en el caso de una novela, años enteros en que uno esta lidiando con borradores grises y feos sin saber si ese proyecto se va a concretar o no. El microrrelato en ese sentido es algo muy placentero.

SB: Porque la relación con la escritura no siempre es de felicidad...

AMS: La primera versión es muy dolorosa, es fea, no es de felicidad. En general cuando estoy trabajando en la primera versión es más lo que sufro que lo que disfruto. En cambio, cuando tengo todo el material ya es puro placer: corregir, cambiar, pulir, reescribir, eso es la literatura y eso es fantástico.

SB: Y la microficción te lo da de entrada.

AMS: Sí, porque se genera una idea sobre la que trabajo y quizás en unas horas ya tengo el resultado. El resultado a veces puede ser negativo, pero eso no importa porque lo tiro y empiezo otro, pero ya tengo el resultado.

SB: Decías que encontraste una manera distinta de narrar, ¿por dónde pasa esa diferencia? ¿Por el lenguaje? ¿Por el uso de recursos? Porque la narrativa "más larga" también juega con el lenguaje y con los mismos recursos.

AMS: Yo no sé decirlo exactamente porque no soy teórica, hago práctica de la literatura. Pero tengo la sensación de que trabajando con microrrelatos encontré muchísimas y muy variadas formas de aproximación y que juego con muchos elementos diferentes y que cuento las cosas de una manera que cada uno de los textos sea inesperado y rompa con las convenciones.

SB: Al momento de escribir microrrelatos, ¿te disponés en "modo microrrelato" para escribirlos?

AMS: Sí, totalmente, solo decido que voy a escribir textos de esa extensión. Cuando no lo decido no se me ocurre ninguno. A veces paso tres o cuatro años entre un libro y otro, y en esos años no se me ocurre ni un solo microrrelato, simplemente porque no me lo propongo. Aparece de distintas maneras: una imagen, a veces por una frase, por una situación, por algo que leí, no hay una sola fuente. $A$ veces sale una idea completa y a veces simplemente una frase juguetona que después tengo que justificar. A veces empiezan por el final. En cambio, la no- 
vela necesita una idea de novela que sirva para escribir antes de empezar. No necesariamente un plan pero si una idea general de qué va a tratar la novela, sobre qué voy a escribir, algo que se pueda decir en una frase. $Y$ cuando escribo un cuento también necesito una idea de cuento, que es diferente de la idea de novela, tengo que pensar en una situación, en una circunstancia, en un hecho en particular. Con la microficción siento una enorme libertad, más libertad porque justamente se puede partir de cualquier cosa, de una palabra, de una frase, de un juego literario, de una situación de la realidad, en fin, de muchísimos elementos disparadores.

SB: Cuando comenzaste a escribir microficciones, ¿escribías con conciencia de género? Porque muchos escritores se entregaron a la escritura de esta forma breve $y$ después vinieron los congresos y la etiquetas de género.

AMS: Claro, la etiqueta se la pusieron los críticos. Para mí esto era "cuento brevísimo", no tenía nada de nuevo y yo sentía que me estaba inscribiendo en una tradición muy argentina. Grandes maestros del cuento trabajaron este género que en ese momento era simplemente cuento brevísimo: Borges, Cortázar, Bioy, Denevi, todos ellos lo escribieron. Hay libros famosos: Cuentos breves y extraordinarios, de Borges y Bioy, Falsificaciones, de Denevi... Además, ellos tienen en sus otros libros, microrrelatos combinados con cuentos más largos. Y hay algo más, yo empecé a escribir mis primeros microrrelatos para presentarlos a un concurso, un concurso de cuentos brevísimos que hacía la revista El Cuento, la revista mexicana dirigida por Edmundo Valadés. Ellos publicaban muchos cuentos brevísimos y tenían una especie de concurso permanente: allí mandé mis primeros textos, los escribí especialmente para ese concurso. Los escribí sin tener ninguna conciencia de género, eran cuentos brevísimos. Hoy está volviendo ese nombre. Porque cuando uno habla con el lector común no especializado, lo de minificción directamente no se entiende; microrrelato parece que fuera algo muy raro... ¡son casi como nombres en latín! Prefiero decirle cuentos brevísimos y todo el mundo me entiende, es una forma de acercarlo al lector.

\section{SB: ¿Tenés tu lector ideal de microficción?}

AMS: Mi lector ideal es un lector muy avezado. Tengo dos lectores ideales completamente opuestos. Por un lado el muy lector, el súper lector, el que entiende todas las referencias literarias y que verdaderamente comprende hasta el fondo cada uno de los textos y para eso hay que ser muy buen lector, un lector muy preparado. Y por otro lado, la gente muy joven que empieza a leer, y que se divierte mucho con la paradoja, con los juegos y con el lenguaje. Por lo menos creo que esos son mis lectores ideales.

SB: Siempre te piden consejos para los noveles escritores y vos tenés tu decálogo. ¿Podrías ofrecerme un par de ítems para un decálogo de lectores de microficción? 
AMS: Punto 1: el lector de minificción tiene que estar preparado para una aventura intensa y breve, tiene que saber que cuando empiece a disfrutar de su nuevo amor inmediatamente se ha terminado. Punto 2: es muy importante que sepa que no puede leer muchos textos seguidos. Los libros de microrrelatos no son para leer de una sentada. Cuando uno se sienta a leer, no hay que leer más de diez textos porque son textos exigentes, requieren mucha atención y producen un cierto efecto de fatiga. Es bueno parar y seguir en otro momento, en ese sentido se parece muchísimo a los libros de poesía. Nadie se sentaría a leer un libro de poesías de una vez.

SB: ¿Por qué creés que sorprende, en más de un sentido, la brevedad de los textos breves y no sorprende la brevedad de la poesía?

AMS: Todo el tiempo recuerdo la existencia de la poesía porque alguno de los problemas que se le encuentran al microrrelato están directamente relacionados con la poesía: les pasa exactamente lo mismo. Entonces muchos de los que acusan al microrrelato de ser un género pasatista o un género de esta época de velocidad donde ya no hay tiempo para nada, yo les digo "¿y la poesía?" . La poesía existió siempre y siempre fue breve, salvo los poemas épicos, y sin embargo no se le hacen acusaciones. Porque la poesía tiene muchos siglos de bien establecido prestigio y el microrrelato recién se está abriendo camino en ese campo y todavía no está del todo legitimado, a pesar de Kafka por ejemplo. Muchos lo desprecian por ser breve y otros creen que por ser breve es fácil y se lanzan a escribir microrrelatos. Yo les suelo pedir a los microrrelatistas que no sean microrrelatistas, no existen los microrrelatistas. Hay escritores, no hay microrrelatistas. Generalmente la gente que solo escribe microrrelatos está un poco limitada por el género. Habría que poner una oficina donde se otorguen autorizaciones para escribir microrrelatos donde el autor se presente con un cuento y una novela antes de escribir microrrelatos. Uno no puede ponerse a escribirlos porque no le sale un cuento de cinco páginas, porque si no le sale... el microrrelato no le va a salir tampoco. O va a salir algo muy pobre.

SB: Hay quienes escriben solo poesía, en ese caso ¿como funcionaría esta oficina?

AMS: Es diferente porque la poesía es un género muy amplio y no lo puedo comparar con el microrrelato, lo comparo con la narrativa, no con el microrrelato. El que escribe poesía seguro que no siempre escribió el mismo tipo de poesía, y el que escribe narrativa tiene que probar los otros géneros aunque se sienta más cómodo en uno.

SB: El debate sobre la proliferación de la escritura, la buena y no tanto, se ha elevado con la incursión de estos textos en Internet, que es una plataforma ideal para este género y su difusión. 
AMS: Dos cuestiones trabajaron casi simultáneamente en la difusión del género. Una fue este trabajo de los críticos al decidir que esto era un género diferente del cuento sobre el que no se había escrito nada y valía la pena lanzarse a producir trabajos académicos acerca del tema. Estos críticos a su vez son profesores universitarios y empezaron a trabajar en el género simultáneamente en varios lugares del mundo hispánico, lo que provocó una suerte de "derrame" sobre sus alumnos, y el género empezó a tener más prestigio y más difusión. Por otro lado, simultáneamente apareció la posibilidad de difusión por Internet, al ser un género ideal para leer en pantalla. Y además, hay tanta escritura. Se dice que hay mala escritura, lo mismo pasa con la poesía, hay mala escritura porque simplemente son textos cortos, rápidos. En una noche uno puede escribir fácilmente un pésimo libro de poesía. En cambio escribir una pésima novela lleva muchísimo tiempo de esfuerzo.

SB: ¿Y las formas hiperbrevísimas, los tweets, y los derivados de la tecnología móvil?

AMS: Todo el tiempo me preguntan sobre la relación entre el microrrelato y el Twitter, cosa que me molesta porque es como si me preguntaran por la relación entre la poesía y una hoja de papel. Una hoja de papel puede servir para escribir poesía o cualquier otra cosa, y con un tweet para exactamente lo mismo, como con un mensaje de texto. Es nada más que un formato que se puede usar para cualquier cosa, también por supuesto para literatura. Pero además hay otra idea errónea, que le hace daño al microrrelato, que es que cuanto más corto, más valioso. Hay microrrelatos maravillosos de una página, admirables, extraordinarios, de Kafka, de Borges... El famoso dinosaurio en ese sentido nos ha hecho mucho daño. "El dinosaurio" marca esas siete palabras como el ideal del microrrelato. Un tweet puede servir para escribir frases breves e ingeniosas, para difundir ideas políticas o discutir, o arreglar una cita o lo que sea. Es el equivalente a una hoja de papel.

SB: ¿Notás la mucha tarea de gestión que hay alrededor de este género? Vos misma, por ejemplo, ahora estás trabajando para un concurso. Además de numerosos certámenes, hay blogs, ciclos, revistas, congresos, movidas, eventos.

AMS: En la microficción hay muchos más escritores que lectores. En eso es exactamente igual que en la poesía. Si toda la gente que escribe poesía leyera poesía, la poesía seria best seller. Con la microficción pasa lo mismo, muchísima gente que escribe microficción pero que no la lee. Es maravilloso que exista todo esto, me parece fantástico, lo apruebo y me parece bárbaro. Pero no dejo de preguntarme por qué todos esos cultores no compran libros de microficción. Hay intercambio de libros, pero no circulación de dinero. A la hora de leer es más fácil que se compren una novela. Yo temo que una parte importante de toda esa gente que está trabajando alrededor de la microficción lean poco. Producen más de lo que leen. 
SB: Los libros de microficción no están accesibles, no podés comprarlos en una librería, con algunas excepciones. Es difícil conseguirlos si no vas a esos lugares de intercambio. Hay que buscar y encontrar la joya, también en el caso de los lectores.

AMS: También es cierto, tenés mucha razón. A pesar de estas respuestas medio cínicas y descreídas yo estoy muy contenta con que haya todo este movimiento. Igualmente no deja de ser llamativo que haya tanta gente alrededor del género... Quizá hay mucho trabajo y poca lectura.

SB: Se suele apelar a diversas imágenes para ofrecer una definición de la microficción más cercana a los lectores, ¿cuáles son tus imágenes, además de la de la joya?

AMS: Bueno, a veces es una pirueta del lenguaje, no siempre. Creo que la idea de la piedra me parece muy gráfica porque entonces uno puede explicar que el trabajo del autor de microficción es parecido al trabajo del minero. Uno tiene que encontrar la veta de cómo extraer una piedra, sin saber si es o no es una piedra preciosa. Y después viene el trabajo del joyero, y con el trabajo del joyero, con el corte y el pulido llegás a ver si era o no era lo que uno pensaba. A veces también hablo de las microficciones como pirañas, porque son muchas, veloces, muerden, sobre todo muerden si son buenas, si no muerden no son pirañas y una vez más, no son microficciones. 